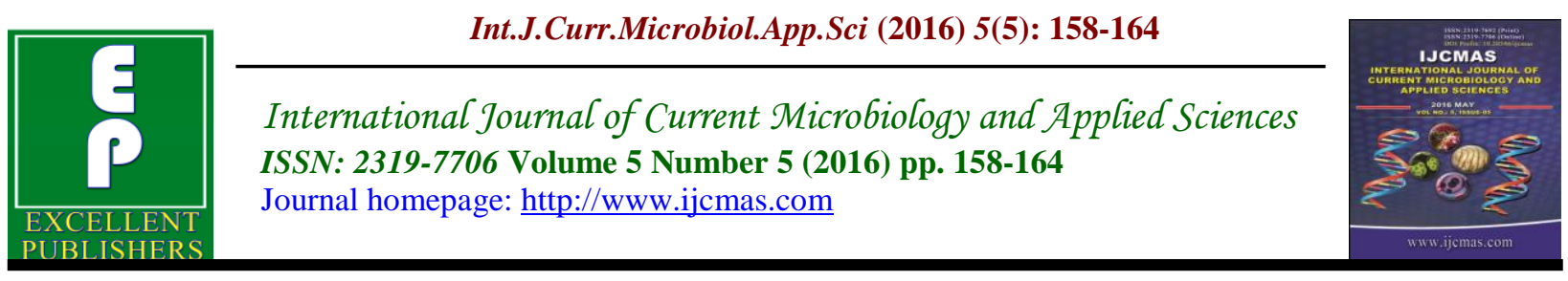

Original Research Article

http://dx.doi.org/10.20546/ijcmas.2016.505.017

\title{
Isolation and Scrutinize of Marine Actinomycetes Metabolites against Clinical Pathogens
}

\author{
K. Ramarajan and P. K. Senthilkumar* \\ Department of Microbiology, Faculty of Sciences, Annamalai University Tamil Nadu, India \\ *Corresponding author
}

\begin{tabular}{|c|c|}
\hline & A B S T R A C T \\
\hline & \multirow{10}{*}{$\begin{array}{l}\text { To isolation and identification proof of optional metabolites producing } \\
\text { marine Actinomycetes against clinical bacterial pathogens. To scrutinize the } \\
\text { bioactive compound from isolated actinomycetes. Marine Actinomycetes } \\
\text { isolated from seashore samples from different places of Nagapattinam, } \\
\text { Velankani, and Karaikal in India. Antimicrobial substances from marine } \\
\text { Actinomycetes were identified by cross streak method and agar plate } \\
\text { method. The potent Actinomycetes species were inoculated on production } \\
\text { medium and extracted. The extracted compound was screened for } \\
\text { antibacterial activity. Fifteen Actinomycetes species were isolated from the } \\
\text { selected marine soil sample. All the fifteen isolates were active against the } \\
\text { test organisms. Chemical screening strongly suggested that presence of } \\
\text { alkaloids, Flavonoids, Carbohydrates and Glycosides. The result of marine } \\
\text { Actinomycetes is composed of potent secondary metabolites. Isolation, } \\
\text { screening of marine Actinomycetes can be useful in discovery of novel } \\
\text { metabolites. }\end{array}$} \\
\hline Keywords & \\
\hline rine & \\
\hline $\begin{array}{l}\text { Actinomycetes, } \\
\text { Chemical }\end{array}$ & \\
\hline $\begin{array}{l}\text { Screening, } \\
\text { Antimicrobial } \\
\text { activity, }\end{array}$ & \\
\hline $\begin{array}{l}\text { Cross-streak } \\
\text { method. }\end{array}$ & \\
\hline Article Info & \\
\hline $\begin{array}{l}\text { Accepted: } \\
\text { 12 April } 2016\end{array}$ & \\
\hline Available Online: & \\
\hline & \\
\hline
\end{tabular}

\section{Introduction}

Actinomycetes are aerobic, reproductive structure forming gram-positive bacteria, happiness to the order Actinomycetales characterised with substrate and aerial mycelium growth (Lechevalier and Lechevalier, 1981). It's a high G+C magnitude relation of the desoxyribonucleic acid $(>55 \mathrm{~mol} \%)$, that are phylogenetically connected from the proof of $16 \mathrm{~S}$ ribosomal cataloguing and DNA:rRNA pairing studies (Goodfellow and Williams, 1983; KornWendisch and Kutzner, 1992 ).
It represents one in every of the biggest taxonomical units among the 18 major lineages presently recognized inside the domain bacteria (Ventura et al., 2007). Nature acts as a distinguished reservoir for brand new and novel medical specialty. By using subtle techniques in varied screening programs, the speed of discovery of natural compounds exceeds one million. Out of 22,500 biologically active compounds that are extracted so far from microbes, $45 \%$ are made by Actinobacteria, 38th by fungi and terrorist organization by living thing bacteria (Demain and sanchez, 2009). Sadly, the 
emergence of drug-resistant pathogens and also the increase in diseases touching the system have greatly intense the necessity to analyze new bioactive metabolites for potential pharmaceutical and industrial applications (Demain and sanchez, 2009; Wise, 2008).

The look for new antimicrobials has not been restricted to the medicative field, however conjointly extends to crop protection. Advancement of fungicide-safe plant pathogens and in addition over the top and unpredictable utilization of engineered agrochemicals has prompted biological irregular characteristics in soil and human wellbeing (Thind, 2008). The bioactive secondary metabolites created by Actinomycetes embody antibiotics, antitumour agents, immunological disorder agents and enzymes. These metabolites are known not antibacterial, antifungal, cell reinforcement, neutrogenic, hostile to growth, against algal, hostile to helmintic, hostile to malarial and mitigating (Kekuda et al., 2010; Ravikumar et al., 2011). This study evaluates isolation, identification; chemical screening and antibacterial activity of living thing compounds against different types of infectious agent that were gift in Actinomycetes, the pathogens were used Pseudomonas aeruginosa, E coli, staphylococcus aureus, Klebshilla pneumonia and Bacillus subtilis.

\section{Materials and Methods}

\section{Sample Collection}

Soil samples were collected $10 \mathrm{~cm}$ below the surface of seashore soil from the areas of Nagapattinam, Velanganni and Karaikal. Soil samples were air-dried under room temperature for about 10 days before isolation.

\section{Isolation of Actinomycetes}

Soil tests gathered were pretreated by drying hot air broiler at $40^{\circ} \mathrm{C}$ for 2 days. Tests of 1 $\mathrm{g}$ each were blended with $10 \mathrm{ml}$ of clean refined water and hatched at room temperature $\left(25 \pm 2^{\circ} \mathrm{C}\right)$ for $1 \mathrm{~h}$ on orbital shaker with vivacious shaking. Soil suspension was then pipetted and unfolds onto humic substance B-Vitamin (HV) agar (Hayakawa et al., 2004) and incubated at $30^{\circ} \mathrm{C}$ for seven days.

\section{Characterization of Actinomycetes}

The actinomycetes selected after secondary screening, were characterized by morphological and bio chemical method. Morphological characterizations were done by microscopic method. The microscopic characterization was done by cover slip culture method (Kawato and Sinobu, 1959).

The mycelium structure, color and arrangement of conidiospore and arthrospore on the mycelium were observed through the oil immersion (100X). The observed structure was compared with Bergey's Manual of Determinative Bacteriology, Ninth edition (2000) and the organism was identified. Various biochemical tests performed for the identification of the potent isolates are as follows: starch hydrolysis, Indole, methyl red, temperature tolerance, $\mathrm{NaCl}$ resistance.

\section{Screening of Actinomycetes for Antimicrobial Activity}

The screening procedure was finished by following techniques procedure described by Liu et al., (2011).

\section{Primary and Secondary Screening}

In essential screening the antimicrobial 
movement of isolated disconnects were controlled by cross streak technique on ken knight agar. The test living beings utilized were Pseudomonas aeruginosa, E coli, Staphylococcus aureus, Klebsiella pneumoniae and Bacillus subtilis. Auxiliary screening was performed by agar well diffusion methods against the standard test organisms.

\section{Chemical Screening}

Chemical tests were carried out on the ethyl acetate extract of Actinomyctes using standard procedures to identify described by Harborne et al., (1973); Trease et al., (1989).

\section{Test for Carbohydrates}

To $2 \mathrm{ml}$ of concentrate, $1 \mathrm{ml}$ of Molisch's reagent and few drops of concentrated sulphuric acid were included. Purple shading arrangement showed the vicinity of carbohydrates.

\section{Test for Flavonoids}

To $5 \mathrm{ml}$ of weaken ammonia solution was added to a segment of the fluid filtrate of concentrate took after by option of focused sulphuric acid. Look of yellow colouration demonstrated the vicinity of flavonoids.

\section{Test for Alkaloids}

To $2 \mathrm{ml}$ of extract, $2 \mathrm{ml}$ of focused hydrochloric acid was added. Then few drops of Mayer's chemical agent were added. Presence of green color indicated the presence of alkaloids.

\section{Test for Glycosides}

To $2 \mathrm{ml}$ of extract, $3 \mathrm{ml}$ of chloroform and 100 percent ammonia resolution was added. Pink color formation indicated the presence of glycosides.

\section{Test for Phenols}

To $1 \mathrm{ml}$ of the extract, $2 \mathrm{ml}$ of $\mathrm{H}_{2} \mathrm{O}$ followed by few drops of 100 percent metallic element chloride was added. Formation of inexperienced color indicated the presence of phenols.

\section{Test for Tannins}

To $1 \mathrm{ml}$ of extract, $2 \mathrm{ml}$ of $5 \%$ metallic element chloride resolution was added. Formation of chromatic black color indicated the presence of tannins.

\section{Test for Saponins}

To $2 \mathrm{ml}$ of extract, $2 \mathrm{ml}$ of $\mathrm{H}_{2} \mathrm{O}$ was added and jolted in an exceedingly graduate for 15 minutes lengthwise. Formation of $1 \mathrm{~cm}$ layer of froth indicated the presence of saponins.

\section{Results and Discussion}

A total of fifteen isolates were isolated from soil samples. The quantity of samples and isolates in every sample were given in Table 1. Out of 15 isolates, 5 cultures i.e. N3, N11, V5, V6, and K9 were the 5 strains elite for any analysis, since they showed important medicinal drug activity against check organisms and chemical screening Table 2 and 3. As for because the 5 cultures involved, the 2 cultures $\mathrm{N} 11$ and $\mathrm{K} 9$ have most activity against check organisms. Then N11 and K9 were known and confirmed by microscopic and macroscopical examination. N11 strain could be a gram positive, cocci in nature, long reproductive structure chain, and filamentous bacterium. K9 strain could be a gram positive, Cocci with spiral reproductive structure chain bacterium. The macroscopical look of the isolate N11 showed leather like, white powdery colonies in starch casein agar 
media whereas K9 showed inexperienced powdery colonies. The isolates conjointly created antimicrobial compounds. Two elite isolates i.e. $\mathrm{N} 11$ and $\mathrm{K} 9$ were tested for the antimicrobial activity against test organisms are given Table 4 among the two isolates, the very best inhibition was shown by the cultures N11 and K9 against Staph aureus. Cultures K9 showed activity against Pseudomonas aeruginosa, E. coli, staphylococcus aureus, Klebseilla pneumoniae and bacillus subtilis Figure 1(a,b,c,d and e).

Actinomycetes comprise $100 \%$ of the overall microorganism colonizing marine aggregates. Marine natural surroundings have been demonstrated as a remarkable and captivating asset for developing new and strong bioactives creating microorganisms. Marine microbes are notably engaging as a result of they need the high efficiency needed for bioactive compounds to be effective within the marine surroundings, attributable to the diluting result of ocean water. Members of the Actinomycetes, that board marine surroundings, are poorly understood and solely few reports are on the market.

Table.1 Isolation of Actinomycetes from Marine Soil Samples

\begin{tabular}{lllll}
\hline S.No. & $\begin{array}{l}\text { Geographical } \\
\text { locations }\end{array}$ & Sampling spots & Types of sample & $\begin{array}{l}\text { Number of } \\
\text { isolates }\end{array}$ \\
\hline 1 & Nagapattinam, & Sea shore soil & Soil sample with water & 4 \\
2 & Velanganni & Sea shore soil & Soil sample & 8 \\
3 & Karaikal & Sea shore soil & Soil sample with water & 3 \\
\hline
\end{tabular}

Table.2 Preliminary Screening of Actinomycetes for Antimicrobial Activity by Cross-Streak Method

\begin{tabular}{lllllll}
\hline Isolates & $\begin{array}{c}\text { Pseudomonas } \\
\text { aeruginosa }\end{array}$ & E. coli & $\begin{array}{c}\text { Staphylococcus } \\
\text { aureus }\end{array}$ & $\begin{array}{c}\text { Klebsiella } \\
\text { pneumoniae }\end{array}$ & $\begin{array}{c}\text { Bacillus } \\
\text { subtilis. }\end{array}$ \\
\hline V1 & - & + & - & & - & - \\
V2 & + & - & - & - & + \\
V3 & - & - & - & - & + \\
V4 & + & - & - & - & + \\
V5 & - & - & - & - & - \\
V6 & - & + & - & - & + \\
V7 & - & - & - & - & + \\
V8 & - & - & + & - & + \\
K9 & + & - & + & + & + \\
K10 & - & + & - & - & + \\
N11 & + & + & + & + & + \\
N12 & - & - & - & - & + \\
N13 & - & - & - & - & - & - \\
N14 & - & - & - & - & - & + \\
N15 & - & + & - & - & - & + \\
\hline
\end{tabular}


Table.3 Chemical Screening for Isolated Actinomycetes

\begin{tabular}{|c|c|c|c|c|c|c|c|c|c|c|c|c|c|c|c|c|}
\hline Test & Response & $\begin{array}{l}\mathrm{V} \\
\mathbf{1} \\
\end{array}$ & $\begin{array}{l}\mathrm{V} \\
2 \\
\end{array}$ & $\begin{array}{l}\mathrm{V} \\
\mathbf{3} \\
\end{array}$ & $\begin{array}{l}V \\
4 \\
\end{array}$ & $\begin{array}{l}\mathrm{V} \\
5 \\
\end{array}$ & $\begin{array}{l}\mathrm{V} \\
6 \\
\end{array}$ & $\begin{array}{l}\mathrm{V} \\
7 \\
\end{array}$ & $\begin{array}{l}\mathrm{V} \\
8 \\
\end{array}$ & $\begin{array}{c}K \\
9\end{array}$ & $\begin{array}{c}\text { K1 } \\
\mathbf{0} \\
\end{array}$ & $\begin{array}{c}\text { N1 } \\
1\end{array}$ & $\begin{array}{c}\text { N1 } \\
2 \\
\end{array}$ & $\begin{array}{c}\text { N1 } \\
3 \\
\end{array}$ & $\begin{array}{l}\mathrm{N} \\
14\end{array}$ & $\begin{array}{c}\text { N1 } \\
5 \\
\end{array}$ \\
\hline Carbohydrates & $\begin{array}{l}\text { Purple } \\
\text { colour }\end{array}$ & + & + & + & + & + & + & + & + & + & + & + & + & + & + & + \\
\hline Flavonoids & $\begin{array}{c}\text { Yellow } \\
\text { colouration }\end{array}$ & - & - & + & - & + & - & + & - & + & - & + & - & + & - & + \\
\hline Alkaloids & $\begin{array}{c}\text { Presence of } \\
\text { green } \\
\text { colour. }\end{array}$ & + & + & + & + & + & + & + & + & + & + & + & + & + & + & + \\
\hline Glycosides & $\begin{array}{l}\text { Pink colour } \\
\text { Formation }\end{array}$ & + & + & + & + & + & + & + & + & + & + & + & + & + & + & + \\
\hline Phenols & $\begin{array}{l}\text { of green } \\
\text { colour. }\end{array}$ & - & - & - & - & - & - & - & - & - & - & - & - & - & - & - \\
\hline Tannins & $\begin{array}{l}\text { Formation } \\
\text { of block } \\
\text { colour. }\end{array}$ & - & - & - & - & - & - & - & - & - & - & - & - & - & - & - \\
\hline Saponins & $\begin{array}{l}\text { Formation } \\
\text { of foam } \\
\text { layer }\end{array}$ & - & - & - & - & - & - & - & - & - & - & - & - & - & - & - \\
\hline
\end{tabular}

Figure.1 Antibacterial Activity of Marine Actinomycetes

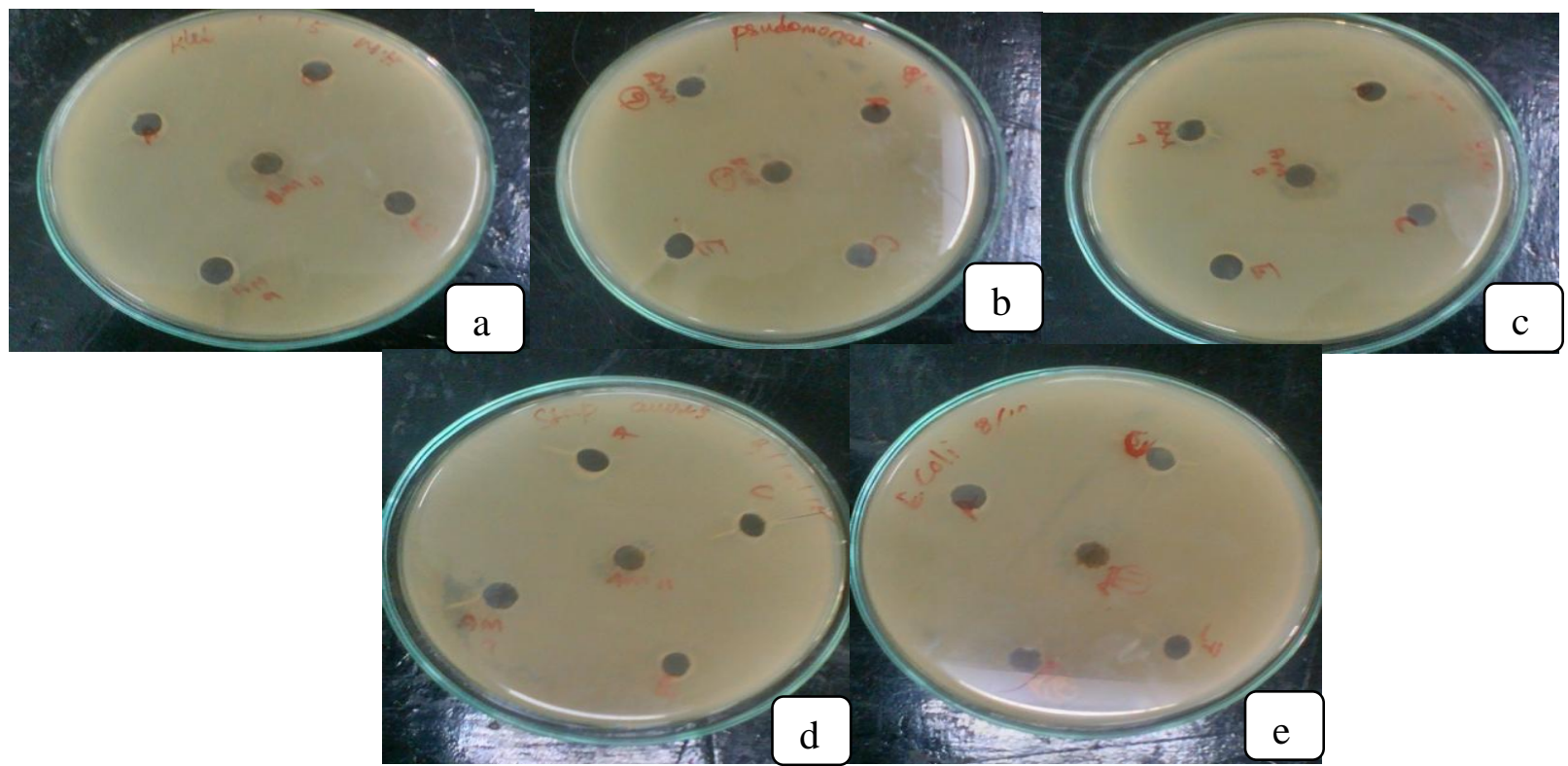

a. Kleb. pneumonia, b. Psudomonous auroginosa, c. Bacillus subtilis, d. Staph. aureus and e. E. coli 
Table.4 Antimicrobial Activity

\begin{tabular}{llllll}
\hline $\begin{array}{l}\text { Sample } \\
\text { No }\end{array}$ & $\begin{array}{l}\text { Staph. } \\
\text { aureus }\end{array}$ & E. Coli & $\begin{array}{l}\text { Kleb. } \\
\text { pneumoniae }\end{array}$ & B. subtilis & Psudo. auroginosa \\
\hline N11 & $19 \mathrm{~mm}$ & $8 \mathrm{~mm}$ & $12 \mathrm{~mm}$ & $10 \mathrm{~mm}$ & $11 \mathrm{~mm}$ \\
K9 & $20 \mathrm{~mm}$ & $15 \mathrm{~mm}$ & $18 \mathrm{~mm}$ & $13 \mathrm{~mm}$ & $19 \mathrm{~mm}$ \\
\hline
\end{tabular}

Actinomycetes account 70th of the earth's surface and represent engaging supply for isolation of novel microorganisms and production of potent bioactive secondary metabolites (Usha et al., 2011). This study was aimed to isolate Actinomycetes from marine surroundings and screen them for the assembly of secondary metabolites.

In the current study the medium was supplemented with amphotericin B to eliminate the fungus contamination. Constant methodology was antecedently done by Remya and Vijayakumar (2008) Production of antibiotic substance is ocean water dependent. Within the present study additionally, the Actinomycetes isolation agar medium was ready victimization sterile ocean water. Okazaki and Okami (1972) ascertained that compared to alternative Actinomycetes, Actinomycete species showed economical antagonistic activity. This was like the current investigation that additionally showed economical antagonistic activity of Actinomycete species. The isolated Actinomycetes were known supported the colony morphology and Gram staining (Holt et al., 1994). Within the present work, we've got known the Actinomycetes by the presence of pulverized colonies on the surface of agar plate. Actinomycetes are gram positive and thin in nature. According to Kokare et al., (2004) throughout the screening of the novel secondary metabolites, Actinomycetes isolates are usually encountered that showed additional active antimicrobial activity against gram positive bacterium than gram negative bacterium. Actinomycete species showed important antibacterial activity against Staphylococcus aureus and Pseudomonas aeruginosa. This was just like this finding. Within the current study, conjointly the Actinomycete species showed an honest antimicrobial activity against Coccus species, B. subtilis, than gram negative Pseudomonas species and Klebseilla pneumoniae. this study united with the sooner findings of Devi et al., (2006) within which it's been reported that Actinomycete species showed important antimicrobial activity against Staph aureus, Pseudomonas aeruginosa, Klebseilla pneumoniae and Vibrio cholera.

In conclusion, According to marine Actomycetes, which have specific secondary metabolites from the isolated colonies (K9 and N11).

\section{Acknowledgement}

Authors are awesome grateful to the Dr. R. Karuppasamy, Professor \& Head, Department of Zoology, Annamalai University, Chidambaram, Tamilnadu in India.

\section{References}

Demain, A.L., Sanchez, S. 2009. Microbial drug discovery: 80 years of progress. $J$. Antibiot., 62: 5e16.

Devi, N.K.A., Jeyarani, M., Balakrishnan, K. 2006. Isolation and identification of marine actinomycetes and their potential in microbial activity. Pak. J. Biol. Sci., 
9: 470-472.

Goodfellow, M., Williams, S.T. 1983. Ecology of Actinomycetes. Annu. Rev. Microbiol., 37: 189-216.

Harborne, J.B. 1973. Phytochemical methods. Chapman and Hall Ltd., London, pp. 49188.

Hayakawa, M., Yoshida, Y., Iimura, Y. 2004. Selective isolation of actinomycetes belonging to the Streptomyces violaceusniger phenotypic cluster. $J$. Appl. Microbiol., 96: 973e981.

Holt, J.G., Krieg, N.R., Sneath, P.H.A., Staley, J.T., Williams, S.T. 1994. Bergey's manual of determinative bacteriology. 9th ed. Baltimore: Williams and Wilkins; p. 518-537.

Kawato, M., Shinobu., R. 1959. A simple technique for the microscopical observation, memoirs of the Osaka University Liberal Arts and Education. 114.

Kekuda, T.R.P., Shobha, K.S., Onkarappa, R. 2010. Studies on antioxidant and anthelmintic activity of two Streptomyces species isolated from Western Ghat soils of Agumbe, Karnataka. J. Pharm. Res., 3: 26-9.

Kokare, C.R., Mahadik, K.R., Kadam, S.S., Chopade, B.A. 2004. Isolation, characterization and antimicrobial activity of marine halophilic Actinopolyspora species AH1 from the west coast of India. Curr. Sci., 86: 593597.

Lechevalier, H., Lechevalier, M.P. 1981. Introduction to the order Actinomycetales. In: Starr MP, Stolp H, Trüper HG, Balows A, Schlegel HG,Editors. The Prokaryotes. Germany: Springer-Verlag. Berlin., 2: 1915-22.

Liu, Q.G., Ren, P.G., Wang, L.X., Zhao, Y.
2011. Statistical optimization of key medium components by response surface methodology to promote ganoderic acid formation by medicinal mushroom Ganoderma sinense in submerged culture. J. Med. Plant. Res., 5(3): 425-431.

Okazaki, T., Okami, Y. 1972. Studies on marine microorganisms II. Actinomycetes in Sagami Bay and their antibiotic substances. J. Antibiot., 25: 461-466.

Ravikumar, S., Inbaneson, S.J., Uthiraselvam, M., Priya, S.R., Ramu, A., Banerjee, M.B. 2011. Diversity of endophytic actinomycetes from Karangkadu mangrove ecosystem and its antibacterial potential against bacterial pathogens. J. Pharm. Res., 4: 294-6.

Remya, M., Vijayakumar, R. 2008. Isolation and characterization of marine antagonistic actinomycetes from west coast of India. Med. Biol., 15: 13-19.

Thind, T.S. 2008. Fungicide resistance: a perpetual challenge in disease control. $J$. Mycol. Plant. Pathol., 38: 407e418.

Trease, G.E., Evans, W.C. 1989. Pharmacognsy 11th edition Brailliae Tiridal Can. Macmill and Publishers.

Usha, Y., Koppula, S., Vishnuvardhan, Z. 2011. Bioactive metabolites from marine sediments (Streptomyces species) of three coastal areas. Drug. Invent. Today., 2: 114-117.

Ventura, M., Canchaya, C., Tauch, A., Chandra, G., Fitzgerald, G.F., Chater, K.F., et al. 2007. Genomics of Actinobacteria: Tracing the evolutionary history of an ancient phylum. Microbiol. Mol. Biol. Rev., 71: 495-548.

Wise, R. 2008. The worldwide threat of antimicrobial resistance. Curr. Sci., 95: $181 \mathrm{e} 187$.

\section{How to cite this article:}

Ramarajan, K., and Senthilkumar, P. K. 2016. Isolation and Scrutinize of Marine Actinomycetes Metabolites against Clinical Pathogens. Int.J.Curr.Microbiol.App.Sci. 5(5): 158164. doi: http://dx.doi.org/10.20546/ijcmas.2016.505.017 